\title{
Analysis of the Language in the Journal Accredited By the Ministries of Research, Technology, and Higher Education in Indonesia
}

\author{
Kundharu Saddhono ${ }^{1}$ \\ ${ }^{1}$ Universitas Sebelas Maret Surakarta, Indonesia \\ kundharu_s@staff.uns.ac.id
}

\begin{abstract}
The purpose of this study is to describe and to explain the language principle and scientific articles editing in the study of social sciences, humanities, and education in Central Java and Yogyakarta toward reputable journals. Technique of collecting data in the form of text was conducted by document analysis, reading, and literature techniques while the data collection techniques in the form of interviews was conducted by interview techniques. Journal Yustisia (Universitas Sebelas Maret), Journal Komunitas (State University of Semarang), Journal Humaniora (Gadjah Mada University), and Journal Adabiyyat (State Islamic University of Sunan Kalijaga Yogyakarta). Furthermore, the data were analyzed by using interactive text analysis techniques proposed by Miles and Huberman based on CARS theory proposed by Swales and 4 Move Abstract theory by Bhatia. Validity of data in this research used source or data triangulation. The result of the research indicated that concerned journals became has fulfilled the language principle and editing towards reputable journals because all journals have been accredited by Research, Technology and Higher Education Ministr y. The results of this study directly support in improving the quality of scientific journals in Central Java and Yogyakarta. By the enhancement of scientific journals quality will give huge impact on improving the quality of publications, research, and quality of education in general and support academic community character. It also supports the development scientific and academic cultures in university particularly in Central Java and Yogyakarta. The suggestion for concerned journals is to become internationally reputable, English should be improved as the media. Well managed journal in Central Java and Yogyakarta eventually will become internationally known scientific journal.
\end{abstract}

Keywords: Reputable Scientific Journals, Writing, Management, Central Java And Yogyakarta

\section{INTRODUCTION}

The quality of international universities is now the benchmark in rating i.e. 4ICU, Webometrics, TH-QS, and others. One of the aspects that is being assessed by various versions is the scientific work produced by university. Therefore, as technology and science evolve will directly or indirectly result in more scientific work. With this present situation, academics and 
lecturers especially in Indonesia are competing in producing scientific papers to show their contribution to the advancement of science as well as the incentives provided by the government and others. Facing this phenomenon, many scientific research journals in various fields emerged to publicize these new discoveries to the public as research. However, not all lecturers and academics have the ability and competence to compose and write good scientific journal articles to be published in accredited journals.

National Education Ministry Order Number 22 year 2011 specifies some of the requirements for journals as criteria of the accredited journals in article 8 , such as: (1) contains articles that significantly advance knowledge, science, technology and / or art based on research results and a study containing original finds and / or ideas and plagiarism free; (2) has a reputable council or reputable editor who represents the area of knowledge, science, technology, and / or art; (3) involvesintellectuals from various universities and / or research and development agencies and industries different from within and / or abroad that filter the script anonymously; (4) written in the Indonesian language and / or the official language of the United Nations; (5) maintaining the style of writing and its appearance format; (6) published in print and electronically through information and communication technology networks; And (7) meet the published schedule.

At this time the scientific journals published in Indonesia have been very numerous and good journals are categorized in accredited journals, both from DIKTI and from LIPI. From accredited journals in Indonesia, only less than 0.1 percent are internationally recognized and listed in the Scopus index. List of indexed Indonesian journals n Scopus as of June 2015 are 24 pieces, of which 5 are inactive and were renamed and 19 active. This shows that Indonesia is still far away from other Southeast Asian countries such as Singapore which has 94 International Journals, Malaysia has 45 journals, and Philippines 13 journals. This situation is very urgent and becomes a work to do for Kemendikbud, Dikti, LIPI, BPPT, and other teaching institutions including Kemenag. In relation to that, in 2013 the Directorate General of Higher Education (Dikti Kemendikbud) made a policy so that all undergraduate students, S1, S2 and S3 published the results of their research into scientific journals.

However, the policy is contained in the circular letter of Directorate General of Higher Education No. 152/E/T/2012 on Publication of Scientific Work makes university Indonesia quite restless. In the circular it is said that graduates of the Bachelor's program should produce papers published in scientific journals, graduates of the Master program must have produced papers published in the national scientifically accredited journals of Higher Education and graduates of the Doctorate program must have produced the papers received for publication in international journals. However, until now, the number of international academic journals of Indonesian academic work has not increased significantly. Data per February by 2015 in the official website of the Ministry of Research, Technology and Higher Education shows that up to now, only 17 journals have been Scopus indexed.

There are many factors that cause the journals of Indonesian academics difficult to obtain international recognition. Among other criteria such as the article has to be qualified, by looking at up-to-date topic list and its reference list, writing in accordance with the rules of scientific writing also affects during selection. Abstract Writing, Introduction, Discussion, Conclusions, and Reference Lists are amust thing to consider. This is because those section are important part of publishing articles. Another important thing is related to the lack of structure of scientific and English use of Indonesian lecturers or academics.

Seen based on the introduction writing pattern presented by Swales [1] introduction chapter written by many Indonesian writers have not met these three patterns. Research Deli Nirmala [2] conducted in 2002 showed that the introduction of a journal written by a non-native 
lecturer had no complete rhetorical pattern as suggested by Swales. In addition, Khairil Anwar's research on four language teaching journals, TEFLIN (representing accredited national journals), RELC (accredited language journals at Southeast Asia level), Language Learning (accredited language journals in Europe), and TESOL Quarterly (international language accredited language journals from all over the world). The study suggests that rational steps in the introduction used by Swales [1] are consistently used by three language learning journals (Language Learning, RELC, and TESOL Quarterly), particularly from all three macro steps; Determining the centrality, determining the niche, and putting the niche, while TEFLIN's journal representing the national journal is accredited consistently only using two steps i.e. determining centrality and followed by putting a niche.

\section{RESEARCH METHOD}

This research analyzes the data in the form of texts of scientific articles collected in social and human journal in Central Java and Yogyakarta so that this research is not bound to be anywhere and can be done anywhere. This research is descriptive qualitative research. Qualitative research is a study which aims to understand the phenomena of what the subjects of the study experience, such as behavior, perception, motivation, action, etc., holistically, and in the form of descriptions, in the form of words and languages, in a particular context of nature and use natural methods [3]. This approach is used as it is deemed capable of providing a deep understanding of the model of management and writing of scientific journal articles in the journals of social humanities and humanities in Central Java and Yogyakarta.

Sampling technique is a technique or method to select some of the population members to use as a sample. In this research used purposive sampling technique or purposed sample, meaning to determine the sample with a certain consideration which is considered to give maximum data [4]. The data of this research were articles in scientific journals in social, humanities, and education in Central Java and Yogyakarta. These journals were published by state universities in Central Java and Yogyakarta, namely (1) Sebelas Maret University, (2) Semarang State University, (3) GadjahMada University Yogyakarta, and (4) Islamic State University of Sunan Kalijaga Yogyakarta.

Data collection can be done in a variety of ways. In this study, data collection used two techniques, namely: (1) Analysis of documents, namely the technique of data collection by reading the contents of the document [5]. In this study, the documents analyzed included a collection of scientific articles and scientific journals (2) Interview techniques used to know the opinions of managers and authors of scientific journals.

Once the data is obtained then it should be assessed for its validity. Data validity in qualitative research uses triangulation techniques. Triangulation is a check of data credibility with various data collection techniques and various data sources [6]. This triangulation technique is divided into three kinds, namely: triangulation with source, triangulation with method, and triangulation with theory [3]. In this study used source triangulation. The source triangulation was done by conducting interviews with different sources but addressing the same problem.

This research uses interactive text analysis technique of interactive analysis technique presented by Miles and Huberman [6]. This analysis technique involves three main components: (1) Data Reduction; Due to the large number of data collected, data reduction is required. Reducing data means summing up, picking things up and focus on what matters. This process is conducted by classifying data, removing unnecessary, and then organizing data in such a way to be conclusions. (2) Presentation of Data; After being reduced, the next is to present 
the data. According to Miles and Hubberman the presentation of data in a qualitative is on form of textual form of narrative [6]. (4) Conclusion withdrawing; The third data analysis activity is drawings conclusion and verification. Once the collected data is reduced and presented, then a final conclusion is drawn to answer the problems raised. This study will generally discuss the use of the language and structure of scientific journal articles in the journals of social and humanities in Central Java and Yogyakarta. The research framework, research problems, conducting research and will be presented as follows.

\section{RESULT AND DISCUSSION}

In the Yustisia journal in the title has the title provisions should be no more than 12 words, but in the journal Koesrianti title may be more than 12 words, i.e. 19 words with the title "Protection of Foreign Workers on Domestic Workers (PLRT) Laws From State Viewed From The concept of State Responsibility", Agus Riwanto's Journal contains 14 words, namely" The Correlation of the Regulation of Election System Based on Open Election with Political Corruption in Indonesia", and Journal Sefriani and Sri Wartini are 15 words, namely" Corporate Social Responsibility and State Responsibility Against Economic, Social and Cultural Rights in Indonesia". The authors namesare correct for every article. In the abstract section of the Koesrianti Journal there are still words in foreign languages written not italic, for example: abuse should be abuse[7]. In the part of the keywords in the journal Koesrianti and the journal Sabar Slamet has not been written in alphabetical order, otherwise each keyword should be separated by a semicolon (;) but in this journal only separated by a comma (,) while in the journal Dominikus Ranto there is a mistake on the use of commas (,) as a separator between keywords. In the Introduction section the errors in each journal are usually contained in the first paragraph that should not be jutted into. For the discussion section that in the subchapter heading was not written in capital letters at the beginning of a letter in a word, this was exception to the foregoing. In the journal SabarSlamet there was a word that speaks Indonesian but written italic (italic) should be written in regular letters. For the cover section there was review the sentence in the paragraph in longer form [8]. The journal writing format should be justified, but most errors in the journal were left aligned. In this journal, errors in foreign words writingwere still occurring, foreign words that should be written incline but not written (italic). As for the list of libraries there is a condition of writing a list of libraries should [the author's name. Year. Title. City: publisher]. However in this journal there were still some who were off the guidelines and the author unwritten alphabetically.

In the Komunitas Journal in the Title section should be concise and informative, with a word count no more than 12 , including the word link and the title containing the keywords of the topic. Most articles had met the title writing requirements, which were no more than 12 words. But one of the articles analyzed used the title of more than 12 words, "The Role of Social and Cultural Values in Public Education in Remote Island: A Case Study in Karimunjawa Islands, Indonesia". In the authorship lines the author's name was not given a title, equipped with a complete address where the author worked or learned. If the author was more than two people with different agencies, then all addresses were written on the bottom of the article (footnote) by starring. At this point there were still some errors, which was a sign not a star but a picture of a message. The abstract should be written in one paragraph written in English and Indonesian. But there were some articles that only used one language in abstract writing, which is English only. In the keywords section should consist of 3-5 words, written alphabetically, and between the words separated by semicolons (;), in addition there was one article using the separator mark in the form of comma (,) between keywords. 
The introduction section contained background, problems, and research objectives [9]. In this section it is best to avoid sub writing in the introduction. Most of the articles analyzed were correct according to these requirements. However, there were two journals in the subtitles. In addition there was one journal that had a page length of more than $20 \%$ of the length of the entire article. In the research method (methods) briefly informed about the method used and the whole article was correct. Explanation of this section was briefly written, clear, and nonexaggerated. Result and discussion section overview, this section explained the results of the study clearly [10]. From the analysis results all articles had fulfilled the requirements in writing the results and discussion of the journal articles. In the conclusions written in one paragraph was essentially non-numerical. All articles consisted of more than one paragraph and in the acknowledgement section of the nine articles analyzed, there was only one with this section. In the list of references there were still many errors. Starting from few number of references and the lack of references use (over the past 10 years), and many did not use community journal articles as reference material.

The results of the Humanitarian Journal structure analysis on the title "Automatic Retrieval and The Formalization of Multi Words Expressions With F-Words in the Corpus of Contemporary American English" on the number of titles were written 18 words and in the guidelines no more than 12 words. The author's name was written under the title, without title and in the journal there was an error in the author's name because it was not mentioned completely. The institution, the author's address and the contact person were written by the author's institution, email address, and contact number which was inactive and there was an error in the author's address because it was not listed. In the article "Woman Taboo in Banten Community Culture" found that the length of the manuscript was according to guidelines 15-20 pages and the article only had 12 pages and it was not in accordance. In the agency section there was an error i.e. no author's association or address. Error on keyword section was not written italics. The body consisted of (1) introduction, (2) methods, (3) results and discussion, (4) conclusions [11]. The error found was that there was no method in this article. In an article titled "Dualism Economic on Citizen Credit in Yogyakarta in 1912-1990" the number of pages in the guidelines was 15-20 pages but this article was only 11 pages. In the work unit and the author's address was not listed. The number of words in the abstract in this journal article consisted of 158 words but in the abstract guidebook consisted of a maximum of 150 words.

In an article titled "Oral Tradition of Bhanti-bhanti as a Cultural Communication Media in Wakatobi Community" there was no mistake in association, author's address and the contact person written by the author's institution, email address and contact number. On the body part consisted of (1) introduction, (2) method, (3) result and discussion, (4) conclusion and error was found not in in method. The year's writing on the bibliography should not use brackets. In an article titled "The Role of Gandang Tasa in Developing Spirit and Atmosphere at Tabui Performance in Pariaman" the length of the manuscript according to the guidelines of 15-20 pages but this article was only 14 pages. The title was briefly written and dense, maximum 12 words, contained keywords and should reflect the substance of the problem described on the article body and the mistake was the title consisted of 13 words [12]. In the article titled "The Group Concept of Building Rasun Batalun in the Performance of Talempong Renjeang Anam Salabuhan" the length of the manuscript was only 12 pages but in guidelines was 15-20 pages. In the writing section of association, the author's address, and the contact person were not listed otherwise in the guideline association written by the author's institution, email address, and contact contact number (HP number or phone number). In the abstract provision found that abstracts were written in Indonesian and English, maximum 150 words and written in one paragraph containing (1) objectives, (2) methods, and (3) research results [12]. In the abstract 
section there was no research method and it also appeared on the stem which did not not exclude the research method but in the guide part of the body part consisted of (1) introduction, (2) method, (3) result and discussion, (4) conclusion.

The results of the structure analysis of the Adabiyyat Journal on the article entitled "Culler Semiotic Review of Poetry Sufistis Arab poetry in Al Tasawwuf Fi Al-Syi'r Al-Arabi" by Abd Al Hakim Hassan that the structure of the journal title exceeded 5-15 words. In the journal titled "Life Values in Al-Mutanabbi Poetry" there was an abstract error that was the use of conjunction therefore in the beginning of the sentence. The mistake in the introduction that the word according to Abram caused the subject to becoming unclear which should have been Abram stated. Conjunction writing and found twice in sentence which should be after word and is word and not word and again [13]. The other thing was writing a word between not written a string. As for the journal titled "Symbols and Metaphor Study: Between Transcendentalism and Secular Sufism in Ralph Waldo Emerson's Work" there was an abstract error that was a sign of hypocrisy in a delicate word abolition. Another mistake in the introduction section was that there was a phrase in the middle of the sentence which madethe sentence be biased. Content errors were contained in word writing and capitalization and inconsistencies in phrase writing that have other meanings. The error on the part of the concave was that there was an equivalent incremental writing using a semicolon (;). In the journal article titled "The Perseverance of Arab Women InRa'iyah Al-Amal" there was an abstract error that was incorrect in the writing conjunctions between sentence that was why it was supposed to be. In a journal article titled "Phonetic Behavior in Arabic and Its Implications for Meaning" there was an abstract error that was unambiguous vocabulary and introduction mistakes of non-written italics and unconstitutional numbering of alphabets into numbers In the journal article entitled "Poetry and Proverb - Minangkabau Flora and Fauna Lexical Proverb" there was abstract error that was the writing of the phrase 'sometimes' in the beginning of the sentence made the subject became ambiguous and unclear. The first part of the error is the use of the word 'unfortunately' at the beginning of the sentence in the writing of scientific journals. In a journal article entitled "The Use of Metaphors in Layla Majenun" there was an abstract error that was the use of the 'because' of the conjunction in the beginning of the sentence. The mistake of the content was the writing of the word 'is' is incomplete into's'. In a journal article titled "Fatis Word as Remark of Pragmatics Impoliteness in Family" found mistakes that the author wrote conjunction at the beginning of the error in body was the words technical error word "actually" became "actualy". In a journal article titled "Semiotic Culler on Poetry Review - Sufistis Arabic poetry in Al Taslwuf Al - Ari'r Al - Arabi text by Abd Al Hakim Hassan" there was aintroduction mistake that was the abbreviation that did not use capital letters in the name of Muhammad. The results of the conclusions and closing analysis were as a whole had contained conclusions from the results of the study and the entire contents of the study. The results of the list of libraries were based on alphabetical provisions and international bibliographies.

\section{CONCLUSIONS}

Based on the above study it can be concluded that in general the articles contained in the journal have met the existing criteria. But there are still some things that are not in accordance with the guidelines in the journal. This is due to the fact that the editorial process has not been tightened yet. In addition it is also related to the time of publication of the journal which is too short that the editorial board has limited time in editing the journal. The future phenomenon should be avoided because as a journal that has been accredited automatically the procedure for publishing and printing of the journal is standard. With the adoption of 
standardized procedures it is expected that Indonesian journals will be better and more internationally reputable especially some of the journalists have applied journal articles in English. It further enhances readability globally with well-supported journal websites with open access systems.

\section{REFERENCES}

[1] Swales, J. Genre Analysis. English in Academic \& Research Settings. Cambridge: Cambridge University Press. 1990.

[2] Nirmala, Deli. Struktur Wacana dan Aspek Kebahasaan: Analisis Mengenai Genre Pendahuluan Artikel Jurnal Berbahasa Inggris oleh Dosen Non-Penutur Asli. Kajian Sastra. Vol 25 (4) pp. 173 -183. 2002.

[3] Moleong, Lexy J.Metodologi Penelitian Kualitatif. Remaja Rosdakarya, Bandung. 2004.

[4] Lowenhaupt, Rebecca J. The Language of Leadership: Principal Rhetoric in Everyday Practice. Journal of Education Administration. Vol 52 (4) pp.446-468. 2014.

[5] Wiratno, Tri. Kiat Menulis Karya Ilmiah dalam Bahasa Inggris.Yogyakarta: PustakaPelajar.2003.

[6] Sugiyono. Metode Penelitian Pendidika: Pendekatan Kuantitatif, Kualitatif, dan R\&D. Bandung:Alfabeta.2010.

[7] Freeman, Jane. Fair Terms and Villain's Rhetorical Patterns in The Merchant of Venice. Rhetorica. Vol 20 (2) pp.149 -172.2002

Woprep's Gittescott, Brenda. Revising L etters and Reclaiming Space: The Case for Expanding the Search for Nineteenth-Century-Writing Rhetoric into Imaginative Literature. College English. Vol. 78 (2) pp. 162 182. 2015.

[9] Rifai, Mien A. Gaya Penulisan, Penyuntingan dan Penerbitan Karya Ilmiah Indonesia. GadjahMada University Press. 2011.

[10] Wibowo, Wahyu. Tata Permainan Bahasa Karya Tulis Ilmiah. Jakarta: Bumi Aksara. 2010.

[11] Suryani, Ina, et al. Rhetorical Structures in Academic Research Writing by Non- Native Writers. International Journal of Higher Education. 3 pp. 29-38. 2014

[12] Sundari, Wiwiek. Analisis Struktur pada Genre Abstrak Artikel Berbahasa Inggris. Litera. Vol 4 (1) pp.44-57. 2008.

[13] Santosa, Riyadi. LogikaWacana: Hubungan Konjungtif dengan Pendekatan Linguistik Sistemik Fungsional. Surakarta: UNS Press. 2011. 